\title{
Slit2 Is a Repellent for Retinal Ganglion Cell Axons
}

\author{
Simone P. Niclou, Li Jia, and Jonathan A. Raper \\ Department of Neuroscience, University of Pennsylvania School of Medicine, Philadelphia, Pennsylvania 19104
}

\begin{abstract}
We set out to isolate inhibitory guidance cues that affect retinal ganglion cell (RGC) axons in vitro and that could potentially be involved in RGC pathfinding decisions. Here we describe the biochemical purification of an RGC growth cone collapsing factor from bovine brain membranes and its identification as Slit2. Recombinant human Slit2 collapses and repels RGC growth cones from all quadrants of the chick retina. In the developing mouse visual system, slit2 is expressed in the eye, in the optic stalk, and in the ventral diencephalon. Slit2 expres-
\end{abstract}

sion is strong in anterior ventral diencephalic structures but is absent from the ventral midline where the optic chiasm forms. The putative receptors for Slits, robo1 and robo2, are expressed in the inner retinal layer in which RGCs are located. A comparison of the expression patterns of Slit2 and retinal axon trajectories suggests that slit2 acts as a short range repellent for retinal ganglion cell axons.

Key words: Slit; Roundabout; growth cone guidance; repellent; growth cone collapse; retina; visual system development
The projection of retinal axons to their targets in the brain provides an attractive model system for studying mechanisms of axonal pathfinding. The formation of retinotopic projections in one central target, the tectum, has received considerable attention over the years (O'Leary et al., 1999). However, many interesting guidance decisions are made by retinal ganglion cell (RGC) axons long before the tectum is reached. The first RGCs originate in the central retina and extend axons toward the optic fissure through which they exit the eye. They grow toward the diencephalon in the ventral wall of the optic stalk. Fibers from each eye meet in the optic chiasm at the ventral midline of the diencephalon where, in most animals, they cross to the contralateral side of the brain. In animals with binocular vision, some portion of temporal axons do not cross the midline but connect to ipsilateral targets. In the chick, all RGC axons ultimately cross at the chiasm and grow into the contralateral optic tract in which they ascend dorsolaterally to innervate target nuclei in the forebrain and midbrain.

The retinotectal projection is topographically organized in all animals. In the chick, for example, RGC axons from the temporal retina connect to the anterior tectum, axons from the nasal retina connect to the posterior tectum, axons from the dorsal retina project to the ventral tectum, and axons from the ventral retina project to the dorsal tectum. A large body of work performed over the past decade has led to the identification of some of the molecules involved in target selection within the tectum. In particular, two ligands of the Eph A receptor family, ephrinA2 and

\footnotetext{
Received Dec. 20, 1999; revised March 3, 2000; accepted March 6, 2000.

This work was supported by National Institutes of Health Grants R01-NS33656 and R01-NS26527 to J.A.R., and a combined grant from the Swiss National Foundation, the Ciba-Geigy-Jubilaeums-Stiftung, and a grant from the Ministry of Education of Luxembourg to S.P.N. We are grateful to D. Reim and D. Speicher for the protein microsequencing they performed at the Protein Micro-Chemistry Facility of the Wistar Institute (Philadelphia, PA). We thank Akira Itoh at ASAHI (Japan) for generously providing the hslit 2 cDNA. We also thank Chris Metallo for help in preparing retinal explant cultures and past and present members of the Raper lab for help, advice, and encouragement. We thank Virginia Lee for her kind gift of anti-neurofilament monoclonals.

Correspondence should be addressed to Jonathan Raper, Department of Neuroscience, University of Pennsylvania School of Medicine, 1115 BRB2/3, 421 Curie Boulevard, Philadelphia, PA 19104. E-mail: raperj@mail.med.upenn.edu. Copyright (C) 2000 Society for Neuroscience 0270-6474/00/204962-13\$15.00/0
}

ephrinA5, have been shown to act as repellents for temporal $\mathrm{RGC}$ axons and to be required for the correct ordering of the retinotectal projection in the anteroposterior axis (Cheng et al., 1995; Drescher et al., 1995; Nakamoto et al., 1996; Feldheim et al., 1998; Frisen et al., 1998). Ligand-receptor pairs of the Eph B subtype have been proposed to help define the dorsoventral axis, although experimental evidence for this is not yet conclusive (O’Leary and Wilkinson, 1999).

Considerably less is known about the factors that define earlier stages of RGC pathfinding within the retina, and through the optic stalk, chiasm, and diencephalon toward their target regions. Chondroitin sulfate proteoglycans inhibit RGC neurite outgrowth in vitro and are expressed in the inner retinal layer (Snow et al., 1991). Enzymatic removal of chondroitin sulfates from intact cultured retinas leads to ectopic positioning of RGCs and aberrant, randomly oriented neurite outgrowth within the eye (Brittis et al., 1992). It has been proposed that these molecules play a role in the onset of ganglion cell differentiation and help define the initial orientation of RGC outgrowth. Anti-L1 Fab fragments applied to cultured retinas provoke RGC axons to turn away from the optic fissure (Brittis et al., 1995). It has therefore been proposed that the repellent activity of chondroitin sulfates in the periphery of the eye and the attractive activity of L1 on previously growing RGC axons together help to orient new RGC axons toward the optic disk. Netrin-1 also helps to attract RGC axons to the optic disk in which it is produced. Mice deficient for netrin-1 or its receptor DCC have a reduced number of retinal axons in their optic nerves (Deiner et al., 1997).

Important guidance decisions are taken at the optic chiasm in which fibers from both eyes meet and are guided into the contralateral or ipsilateral optic tract. A population of earlygenerated CD44 and stage-specific embryonic antigen-expressing neurons in the ventral diencephalon are likely to provide cues that help define the location of the chiasm. Ablation of these neurons in mice prevents the formation of the chiasm (Sretavan et al., 1995). However, the guidance cues that are presumably expressed by these cells are not yet known. Another cellular specialization at the midline of the developing chiasm that is thought to provide cues for RGC axons are RC2-positive radial glial cells (Mason 
and Sretavan, 1997). In vitro experiments have shown that dissociated chiasm cells and membranes prepared from them selectively repel ipsilaterally projecting retinal axons but not contralaterally projecting axons (Wizenmann et al., 1993; Wang et al., 1995). This is a contact-dependant process. An additional soluble factor is released from chiasm and floor plate explants that reduces axon outgrowth from all RGCs without affecting their orientation (Wang et al., 1996). Thus, the region of the optic chiasm produces multiple guidance cues with distinct effects on specific populations of retinal axons.

Finally, after passing the chiasm, retinal fibers have to be guided toward their target nuclei in the forebrain and the midbrain. Anterior hypothalamus and epithalamus explants secrete a chemorepellent activity for RGC axons, whereas a stimulatory activity is secreted from thalamic explants (Tuttle et al., 1998). Additionally, FGF receptor signaling appears to be required for target recognition. RGC axons expressing dominant negative FGF receptors make aberrant turns upon approaching the tectum, causing them to bypass rather than enter their target (McFarlane et al., 1996). The enzymatic removal of heparan sulfates, important cofactors of FGF signaling, elicits a similar tectal bypass phenotype (Walz et al., 1997). These data suggest that RGC axons are guided along their trajectory by multiple attractive and repellent guidance cues, only some of which are currently identified.

We therefore set out to isolate inhibitory guidance cues that affect RGC axons and that could potentially be involved in RGC pathfinding. We used the growth cone collapse assay to characterize an activity present in membrane extracts of chick brains that induces the collapse of chick RGC growth cones (Luo et al., 1993). Growth cone collapse is a hallmark for putative repellent activities. Here we describe the biochemical purification of an RGC growth cone collapsing factor from bovine brain membranes and its identification as Slit2. We confirmed that human Slit2 (hSlit2) collapses and repels chick RGC growth cones from all regions of the retina. In the developing mouse visual system, slit2 is expressed in the inner retinal layer, in the optic stalk and in the ventral diencephalon. Slit2 expression is absent from the chiasm. The putative receptors for Slits, robo1 and robo2, are expressed in the inner retinal layer in which RGCs are located. Thus, we have identified Slit2 as a chemorepellent guidance signal for RGC axons, and the expression patterns of ligand and receptor suggest that RGC axons may avoid areas with high slit2 expression.

\section{MATERIALS AND METHODS}

\section{Neural explants and collapse assay}

Retinal explants were obtained from embryonic day 6 (E6) chick retinas that were cut into small pieces, plated onto laminin-coated glass coverslips $(40 \mu \mathrm{g} / \mathrm{ml}$ for $1-2 \mathrm{hr}$ ), and cultured for $18-24 \mathrm{hr}$ in $500 \mu \mathrm{l}$ of F-12 medium (Life Technologies, Gaithersburg, MD) supplemented with 6 $\mathrm{mg} / \mathrm{ml}$ glucose, $2 \mathrm{~mm}$ glutamine, $100 \mathrm{U} / \mathrm{ml}$ penicillin, $100 \mu \mathrm{g} / \mathrm{ml}$ streptomycin, $5 \mu \mathrm{g} / \mathrm{ml}$ insulin, $5 \mathrm{ng} / \mathrm{ml}$ transferrin, $5 \mu \mathrm{g} / \mathrm{ml}$ selenium, $20 \mu \mathrm{g} / \mathrm{ml}$ NGF, $100 \mu \mathrm{M}$ putrescine, $200 \mu \mathrm{M}$ progesterone, and $1 \mathrm{ml}$ of bovine pituitary extract. Hormones were purchased from Sigma (St. Louis, MO), NGF was from Collaborative Research (Bedford, MA), and the pituitary extract was prepared in the lab as described previously (Baird and Raper, 1995). In most cases, the whole retina was used for the collapse assay. In some cases, the dorsal, ventral, nasal, or temporal parts of the retina were used for explant culture (taking the optic fissure as the demarcation line between temporal and nasal halves). Dorsal root ganglia (DRG) were isolated from E7 chick embryos and cultured as described for retinal explants.
The collapse assay was performed by adding a small aliquot of the test solution (volume $<10 \%$ of medium volume) to the cultured neural explants. The explants were incubated for an additional $30 \mathrm{~min}$ at $37^{\circ} \mathrm{C}$ in $5 \% \mathrm{CO}_{2}$ and then fixed with $4 \%$ paraformaldehyde in PBS containing $10 \%$ sucrose for $1 \mathrm{hr}$. Explants were scored for the number of growth cones without lamellipodia or filopodia (collapsed morphology) and the number of spread growth cones (noncollapsed morphology). The data were expressed as the percentage of collapsed growth cones as a proportion of the total number of growth cones counted. Approximately 150 growth cones per condition were scored, and each experiment was repeated at least three times. One collapsing unit $(\mathrm{CU})$ is defined as the amount of activity required in $1 \mathrm{ml}$ of culture medium to induce the collapse of $50 \%$ of growth cones.

\section{Purification of a retinal ganglion cell growth cone collapsing factor}

Membrane preparation from bovine brains. Liquid nitrogen-frozen calf brains were purchased from Pel-Freez Biologicals (Rogers, AR). Each brain was defrosted in $500 \mathrm{ml}$ of HBSS containing $10 \mathrm{~mm}$ HEPES, $\mathrm{pH}$ 7.4, $1 \mathrm{~mm}$ EDTA, $50 \mu \mathrm{M}$ leupeptin, and $10 \mu \mathrm{M}$ nitrophenylguanidinobenzoate. The tissue was disrupted in a kitchen blender and centrifuged at $10,000 \times g$ for $15 \mathrm{~min}$ at $4^{\circ} \mathrm{C}$ in a GS4 rotor. The pellet was washed three times in the supplemented HBSS buffer and then mixed with $2.25 \mathrm{M}$ sucrose in PBS, at a pellet/sucrose ratio of 1:0.8. This was overlaid with HBSS buffer and spun at $12,000 \times g$ for $1 \mathrm{hr}$ at $4^{\circ} \mathrm{C}$. Membranes accumulating at the interface between buffer and sucrose layer were carefully collected, washed three times in $0.5 \times$ PBS with 10 $\mathrm{mm}$ Tris- $\mathrm{HCl}, \mathrm{pH} 7.4$, and stored at $-70^{\circ} \mathrm{C}$ until needed. For the preparative step in which the collapsing factor was isolated, $\sim 12$ bovine brains were processed yielding $\sim 3500 \mathrm{ml}$ membranes.

Protein extraction and chromatography. Proteins were extracted by homogenizing brain membranes in $0.5 \times$ PBS with $10 \mathrm{~mm}$ Tris- $\mathrm{HCl}, \mathrm{pH}$ 7.4 , and $3 \%$ Na cholate at a membrane/buffer ratio of 1:2 with a Dounce homogenizer. The homogenized membranes were centrifuged at 19,000 rpm (SV40 rotor) for $1 \mathrm{hr}$ at $4^{\circ} \mathrm{C}$, and the supernatant was collected. Approximately $7500 \mathrm{ml}$ of supernatant, referred to as the crude membrane extract, was obtained from $2500 \mathrm{ml}$ of membranes. Crude extract $(1500 \mathrm{ml})$ was loaded onto $100 \mathrm{ml}$ Q Sepharose beads (Sigma) prepared in a 6 -cm-wide Econo-column previously equilibrated with $1 \times \mathrm{PBS}$, with $5 \mathrm{~mm}$ Tris, $\mathrm{pH} 7.4$, and $0.1 \%$ cholic acid. The flow through was collected and loaded onto a pre-equilibrated S Sepharose column (Sigma), which was washed with 10 bed volumes of $1 \times$ PBS with $5 \mathrm{~mm}$ Tris, $\mathrm{pH} 7.4$, and $0.1 \%$ cholic acid. Bound proteins were eluted with 3 bed volumes of the same buffer augmented with $0.5 \mathrm{M} \mathrm{NaCl}$. The S eluate was incubated with wheat germ agglutinin (WGA) agarose beads (Vector Laboratories, Burlingame, CA) for several hours $(10 \mathrm{ml}$ beads per $300 \mathrm{ml}$ of eluate). The WGA agarose beads were applied onto a $3 \mathrm{~cm}$ Econo-column, washed with $20 \mathrm{~mm} \mathrm{Na}_{2} \mathrm{HPO}_{4}$, pH 7.2, with $100 \mathrm{~mm} \mathrm{NaCl}, 1 \mathrm{~mm}$ EDTA, and $0.1 \%$ CHAPS, and the bound material was eluted with 4 column volumes of the same buffer with $0.5 \mathrm{M} \mathrm{N}$-acetyl-D-glucosamine added. The WGA eluate was loaded onto a Mono S cation-exchange column (HR5/5; Amersham Pharmacia Biotech, Arlington Heights, IL), preequilibrated with $80 \%$ buffer A $(20 \mathrm{~mm}$ Tris- $\mathrm{HCl}, \mathrm{pH} 7.2$, and $0.1 \%$ CHAPS) and $20 \%$ buffer B (20 mm Tris-HCl, pH 7.2, 0.1\% CHAPS, and $1 \mathrm{M} \mathrm{NaCl})$. WGA eluate $(40-50 \mathrm{ml})$ was applied per run at a flow rate of $0.5 \mathrm{ml} / \mathrm{min}$ and a pressure of 2-2.4 MPa. The activity was eluted using the following elution profile: $80 \%$ A plus $20 \%$ B for $10 \mathrm{~min}, 80-65 \% \mathrm{~A}$ plus $20-35 \%$ B over $1.5 \mathrm{~min}, 65-30 \%$ A plus $35-70 \%$ B over $48.5 \mathrm{~min}$, $30-0 \%$ A plus $70-100 \%$ B over 8 min, and back to $80 \%$ A plus $20 \%$ B over $12 \mathrm{~min}$. Fractions $(1 \mathrm{ml})$ were collected, and the activity of each fraction was determined in the collapse assay. The active fractions from several Mono S runs eluted between 60 and $65 \mathrm{~mm} \mathrm{NaCl}$ were pooled, reapplied to the Mono S column, and reeluted at the same salt concentration using the same elution profile.

\section{Protein gels and Western analysis}

To compare inactive fractions with active ones, fractions from the second Mono S column were pooled into four different pools: inactive pool "a," partially active pool "b" eluted at $0.5 \mathrm{M} \mathrm{NaCl}$, and active pools "c" and "d" eluted at $0.6 \mathrm{M}$ and $0.7 \mathrm{M} \mathrm{NaCl}$. The pools were dialyzed overnight against $20 \mathrm{~mm}$ Tris- $\mathrm{HCl}, \mathrm{pH} 7.2,0.1 \%$ CHAPS, and $100 \mathrm{~mm} \mathrm{NaCl}$, concentrated in a Microcon-100 filter (Amicon, Beverly, MA), and separated on a denaturing $7.5 \%$ polyacrylamide gel. The gel was stained with $0.25 \%$ Coomassie blue in $40 \%$ methanol, $10 \%$ acetic acid, and destained in $10 \%$ methanol, $10 \%$ acetic acid. The $200 \mathrm{kDa}$ protein band 


\begin{tabular}{|c|c|c|c|c|c|}
\hline & Total protein $(\mathrm{mg})$ & Total activity (CU) & Specific activity (CU/mg) & Enrichment (fold) & Recovery (\%) \\
\hline Crude extract & 36,000 & $1,430 \times 10^{3}$ & 40 & 1 & 100 \\
\hline S eluate & 2,580 & $666 \times 10^{3}$ & 258 & 6.5 & 47 \\
\hline WGA eluate & 46.6 & $130 \times 10^{3}$ & $2.8 \times 10^{3}$ & 70 & 9 \\
\hline First Mono S & 2.85 & $48 \times 10^{3}$ & $16.7 \times 10^{3}$ & 420 & 3.3 \\
\hline Second Mono S & 0.143 & $60 \times 10^{3}$ & $419 \times 10^{3}$ & 10,500 & 4 \\
\hline
\end{tabular}

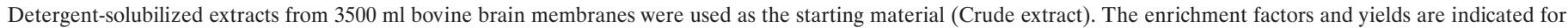

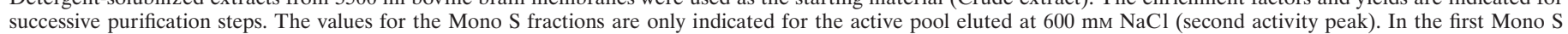

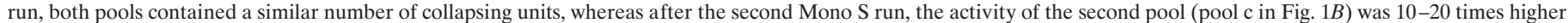

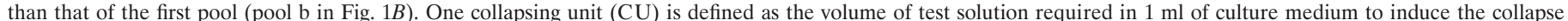
of $50 \%$ of RGC growth cones.

enriched in pool $\mathrm{c}$ was eluted from a preparative gel and digested with trypsin, and selected peptide fragments were microsequenced. Peptide sequence analysis was performed by Dave Reims in the Protein Microchemistry Facility of the Wistar Institute under the direction of D. Speicher (University of Pennsylvania, Philadelphia, PA).

For Western blot analysis, gels were blotted onto an Immobilon $\mathrm{P}$ membrane (Millipore, Bedford, MA). The membrane was blocked for 1 $\mathrm{hr}$ in $1.5 \%$ milk powder in PBS, followed by $2-3 \mathrm{hr}$ treatment with anti-myc antibody (9E10 ascites) 1:2500 in $20 \mathrm{~mm}$ Tris, pH7.4, 1\% FCS, and $0.1 \%$ Triton $\mathrm{X}-100$. After washing, an alkaline phosphataseconjugated anti-mouse antibody (1:1000; Jackson ImmunoResearch, West Grove, PA) was applied, followed by washing and color development with nitroblue-tetrazolium-chloride (NBT) and 5-brom-4-chlorindolyl-phosphate (BCIP).

\section{Cloning and expression of recombinant Slit 2}

For the tagged slit2 construct (myc-his-hslit2), PCR primers corresponding to the $5^{\prime}$ end after the signal sequence and the $3^{\prime}$ end of hSlit2, were used to amplify hSlit 2 cDNA lacking the signal sequence from a human fetal brain cDNA library (Marathon cDNA; Clontech, Cambridge, UK). hSlit2 was cloned into the BamHI and NotI restriction sites of the mammalian expression vector pAG-3 behind the SEMA-3A signal sequence, a double myc-tag, and a 6x His-tag (Koppel et al., 1997). The untagged slit2 construct was obtained by amplifying full-length hSlit2, a generous gift of Dr. Akiro Itoh, and inserting it into a pAG-3 vector with its own signal sequence and without the myc-His tag. 293T cells grown to $70-80 \%$ confluency were transfected with $10 \mu \mathrm{g}$ of plasmid DNA per 6 $\mathrm{cm}$ dish using the calcium phosphate precipitation technique with chloroquine. Four hours after transfection, cells were switched to Optimem medium (Life Technologies) supplemented with $2 \%$ FCS, $6 \mathrm{mg} / \mathrm{ml}$ glucose, $2 \mathrm{~mm}$ glutamine, $100 \mathrm{U} / \mathrm{ml}$ penicillin, $100 \mu \mathrm{g} / \mathrm{ml}$ streptomycin, and $100 \mathrm{ng} / \mathrm{ml}$ heparin. The supernatant was collected after $24 \mathrm{hr}$ and tested in the collapse assay or probed with an anti-myc antibody on Western blots. Cell membranes from cultured cells were prepared with a $4 \mathrm{M}$ urea buffer containing $50 \mu \mathrm{M}$ leupeptin, $2 \mu \mathrm{g} / \mathrm{ml}$ aprotinin, $10 \mu \mathrm{M}$ NPGP, and $100 \mu \mathrm{M}$ PMSF, as described previously (Nguyen Ba-Charvet et al., 1999).

\section{Collagen-matrigel explant cultures}

To prepare collagen gels, we used bovine dermis collagen because it is a better substrate for RGC neurons than rat tail collagen (Wang et al., 1996). Bovine dermis collagen (catalog \#40231; Collaborative Research) was mixed with matrigel (catalog \#40234; Collaborative Research) at a 1:1 ratio in DMEM/F-12 medium supplemented with the same ingredients as used for explant culture on coverslips. Heparin (H-3149; Sigma) was added at a final concentration of $100 \mathrm{ng} / \mathrm{ml}$. Freshly prepared E6 chick retinal explants were placed into a $100 \mu \mathrm{l}$ drop of gel at 200-500 $\mu \mathrm{m}$ away from $293 \mathrm{~T}$ cell aggregates that were either transfected with recombinant hSlit 2 or mock-transfected. Aggregates of transfected cells were obtained by the inverted drop method. Cocultures in collagenmatrigel were grown for $24 \mathrm{hr}$ and fixed in $4 \%$ paraformaldehyde in PBS containing $0.1 \%$ Triton $\mathrm{X}-100$ for $2 \mathrm{hr}$. After inactivation of endogenous peroxidase with $0.3 \% \mathrm{H}_{2} \mathrm{O}_{2}$ in PBS for $1 \mathrm{hr}$, gels were blocked for $1 \mathrm{hr}$ in TBS containing $1 \%$ Triton X-100 and $10 \%$ FCS and then incubated for $2 \mathrm{~d}$ with anti-chick neurofilament antibody (4H6 ascites; used at 1:1000; Cocalico Biologicals, Reamstown, PA). After extensive washing and overnight incubation with a HRP-conjugated secondary antibody (1:
1000; Jackson ImmunoResearch), the color reaction was developed with $0.5 \mathrm{mg} / \mathrm{ml} \mathrm{DAB}$ and $0.03 \% \mathrm{H}_{2} \mathrm{O}_{2}$.

\section{In situ hybridization}

Expressed sequence tag clones of mouse (m) slit1 (GenBank accession number AA049991; $1.6 \mathrm{~kb}$ ], m-slit2 (AA089215; $2.5 \mathrm{~kb}$ ), m-slit3 (AA117086; 1.5kb), and m-robo1 (AA 499193; $2 \mathrm{~kb}$ ) were obtained from Genome Systems Image Consortium (info@genomesystems.com or info@image.llnl.gov) and were used to generate digoxigenin (DIG)labeled riboprobes. A $840 \mathrm{bp}$ fragment of m-robo2 was obtained by reverse transcription-PCR from mouse brain (corresponding to the partial cDNA of hrobo2 published in GenBank under accession number AF040991). Riboprobes were generated by in vitro transcription with digoxigenin-UTP using the DIG RNA Labeling Mix (catalog \#1277 073; Boehringer Mannheim, Indianapolis, IN) and following the manufacturer's instructions. Mouse embryos of developmental stages E12.5, E13.5, E15.5, and E16.5 were obtained from C57/BL6 timed-pregnant female mice, fixed in $4 \%$ paraformaldehyde in PBS overnight at $4^{\circ} \mathrm{C}$, sunk in $30 \%$ sucrose in PBS, embedded in Tissue Tek, and stored at $-70^{\circ} \mathrm{C}$ until use. Sections (30- $\mu$ m-thick) were cut on a cryostat and processed for in situ hybridization as described previously (Shepherd et al., 1996). Hybridization was performed at $72^{\circ} \mathrm{C}$, and color development with NBT and BCIP was for $4-12 \mathrm{hr}$.

After in situ hybridization, the sections were incubated with a rat anti-mouse neurofilament antibody (Ta51 used at 1:500; kind gift of Virginia Lee), followed by a Cy3-conjugated anti-rat antibody (1:1000; Jackson ImmunoResearch). Pictures were taken on a Zeiss (Oberkochen, Germany) Axiovert 35 microscope with a Diagnostic Instruments (Sterling Heights, MI) digital camera using Phase 3 Imaging Systems software. Overlay pictures of neurofilament staining on in situ hybridization signal were produced with the same software.

\section{RESULTS}

\section{Biochemical purification of an RGC growth cone collapsing activity from adult bovine brains}

Previous work has shown that detergent-solubilized membrane extracts prepared from chicken brains induce the collapse of both DRG and RGC growth cones (Luo et al., 1993). SEMA-3A (chick collapsin-1, mouse semaD, human sema-III) was purified from these extracts and induces the collapse of DRG growth cones but does not induce the collapse of RGC growth cones (Luo et al., 1993). Brain extracts therefore contain an activity distinct from SEMA-3A that repels RGC axons. The objective of this work was to purify and characterize this RGC collapsing activity.

Bovine brain membranes served as the starting material for this study because they provide a plentiful source of retinal growth cone collapsing activity biochemically similar to the activity we observed in the purification of SEMA-3A. Flash-frozen calf brains were homogenized, and their membranes were prepared by differential centrifugation. Proteins were extracted in a $3 \%$ sodium cholate buffer, and this crude detergent-solubilized membrane extract was passed through a Q-Sepharose anion-exchange 


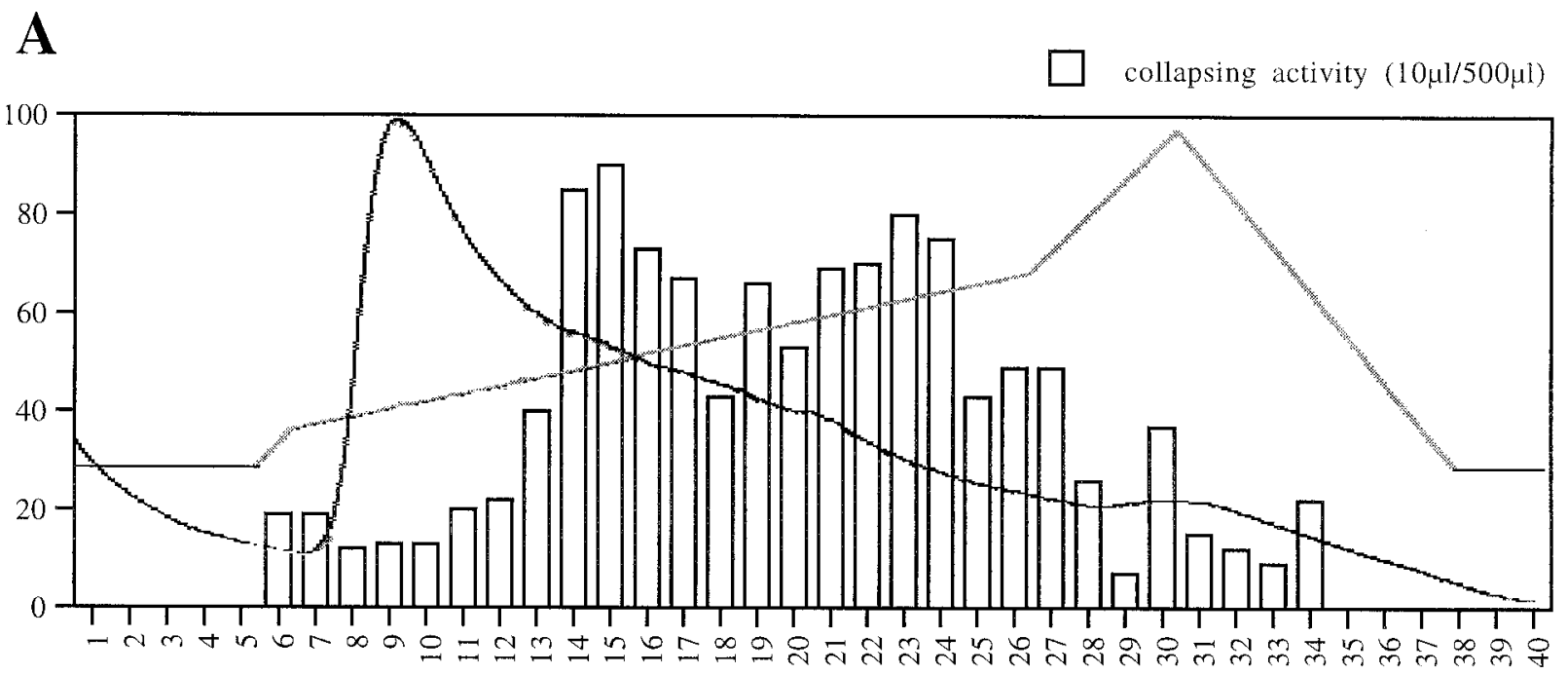

\section{B}

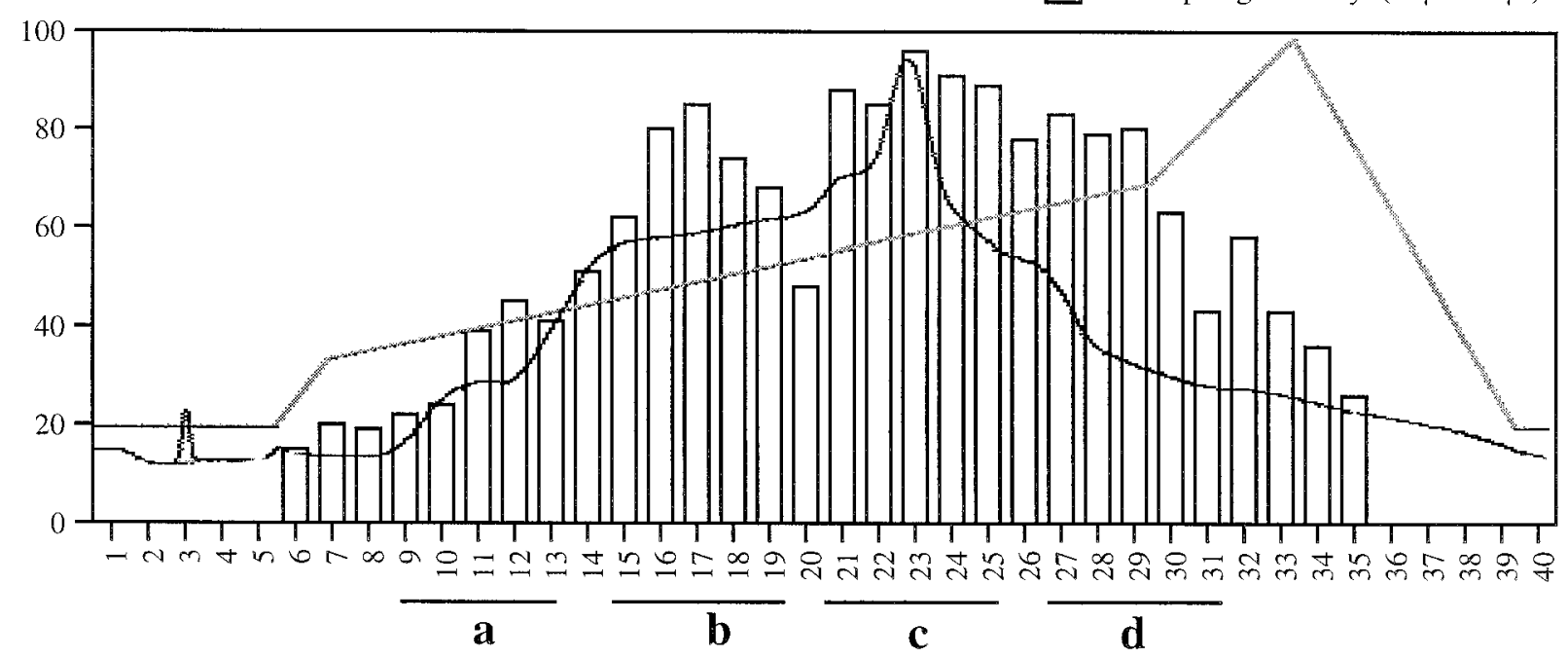

Figure 1. Enrichment of an RGC collapsing activity from bovine brain membranes. The elution profiles of the first $(A)$ and second $(B)$ Mono S columns are shown, along with the collapsing activity (bars in $A$ and $B$ ) of the collected fractions (numbers below the bars). The percentage of growth cones collapsed and the percentage of $\mathrm{NaCl}$ used to elute each fraction are indicated to the left. The first Mono $\mathrm{S}$ column $(A)$ was loaded with wheat germ agglutinin eluate in the presence of $30 \% 1 \mathrm{M} \mathrm{NaCl}$ buffer $(300 \mathrm{mM} \mathrm{NaCl})$, and bound proteins were eluted with an increasing salt gradient (faint line). Most proteins eluted from the column at salt concentrations between 350 and $400 \mathrm{~mm}$ (bold line, O.D. at $280 \mathrm{~nm}$ ). Fractions that were most active in the RGC collapse assay eluted in two peaks at 50\% (fractions 14-17) and 60\% (fractions 20-24) $1 \mathrm{M} \mathrm{NaCl}$ buffer. Both peaks had a similar potency in collapsing RGC growth cones. The second Mono S column $(B)$ was loaded with fractions 20-24 of the first run, corresponding with the second activity peak. Note that the collapsing activity appears again in two peaks at $50 \%$ and $60 \% 1 \mathrm{M} \mathrm{NaCl}$. However, the activity was greatly enhanced (10-20× higher) in the second peak and coincides with a peak of protein eluted from the column (bold line). The letters $a-d$ below the column profile in $B$ indicate fractions that were pooled and compared on a polyacrylamide gel (see Fig. 2).

column. The flow through of the Q-column contained RGC growth cone collapsing activity and was loaded onto an S-Sepharose cation-exchange column. RGC collapsing activity was eluted with a high salt buffer (S eluate) and incubated with WGA-coupled agarose beads. Active WGA-bound material was eluted with $N$-acetyl-D-glucosamine (WGA eluate). Finally, the WGA eluate was applied to two consecutive Mono S cationexchange columns that were eluted with increasing salt concentrations. Fractions $(1 \mathrm{ml})$ were collected and tested for their collapsing activities on RGC growth cones. The enrichments and yields of each step are shown in Table 1.
The most active fractions in the RGC collapse assay eluted from the first Mono $\mathrm{S}$ run in two peaks at 0.5 and $0.6 \mathrm{M} \mathrm{NaCl}$ (Fig. $1 A)$. The amount of collapsing activity was similar in each peak. Active fractions $20-24$ of the $0.6 \mathrm{M} \mathrm{NaCl}$ peak from several runs were combined, reapplied to the Mono S column, and eluted as before (Fig. $1 B$ ). Interestingly, the RGC collapsing activity eluted from the second column in two peaks at 0.5 and $0.6 \mathrm{M} \mathrm{NaCl}$. The measurement of collapsing activity for each fraction of the second Mono $\mathrm{S}$ run, indicated by the bars in Figure $1 B$, reached saturation in fractions 21-29. The bars therefore provide an imperfect estimate of the absolute amount of collapsing activity present in 

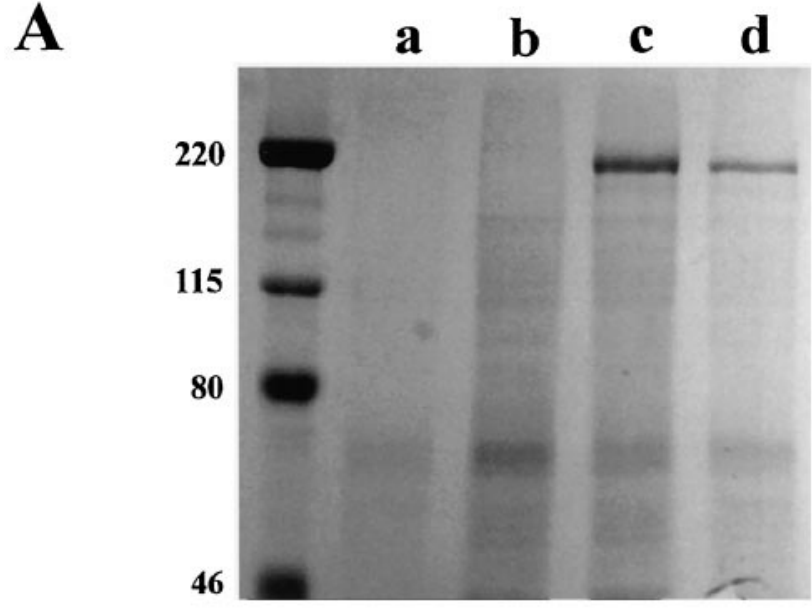

B
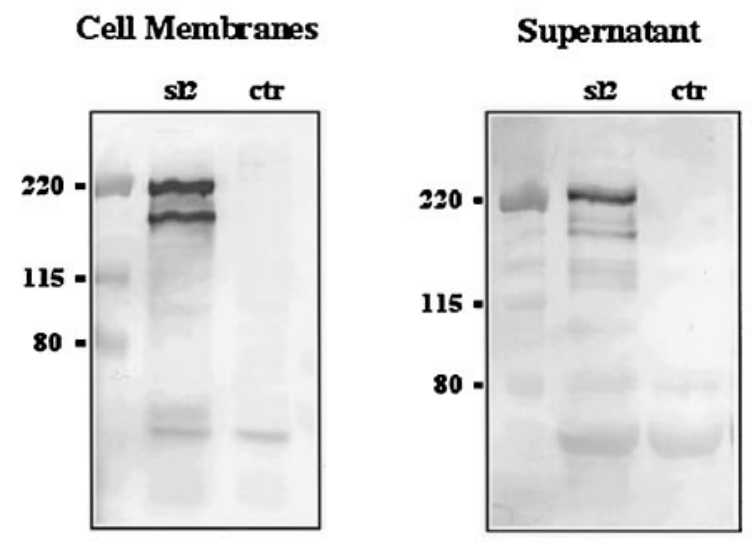

Figure 2. Identification of Slit2 as the RGC collapsing factor. A, Protein gel of purified RGC collapsing factor. Lanes $a-d$ correspond to the pooled fractions from the second Mono S column (as indicated in Fig. 1). The pools were concentrated and were loaded onto a $7.5 \%$ reducing SDS polyacrylamide gel. After separation, the proteins were stained with Coomassie blue. The presence of a single major band at $200 \mathrm{kDa}$ in lanes $c$ and $d$ coincides with the highest collapsing activity in these pools. It is absent from the inactive pool a and undetectable on this gel in the partially active pool $\mathrm{b}$. Molecular weight markers are shown in the left lane. $B$, Western blot of cell membranes and supernatant from transfected 293 T cells visualized with an anti-myc antibody. Cells were either transfected with myc-his-hslit2 (sl2) or mock-transfected (ctr). Note the presence of full-length Slit 2 at $\sim 200 \mathrm{kDa}$ in the membrane fraction and the supernatant, and an N-terminal Slit2 fragment at $\sim 140 \mathrm{kDa}$ that is enriched in the membrane fraction. Molecular weight markers are shown in the left lane.

these fractions. On further analysis, the $0.6 \mathrm{M} \mathrm{NaCl}$ peak was found to be at least 10 times more potent compared with the 0.5 $\mathrm{M} \mathrm{NaCl}$ peak. This was determined by comparison of the doseresponse curves of the two activity peaks (data not shown). The $0.6 \mathrm{M}$ peak of activity coincided with a distinct protein peak eluted from the column (Fig. $1 B$ ). We chose to characterize this peak because it represented the most abundant RGC collapsing activity. From the $\sim 12$ calf brains that were processed, $\sim 60 \times$ $10^{3} \mathrm{CU}$ were recovered in $140 \mu \mathrm{g}$ of protein (Table 1 ).

\section{Identification of a $\mathbf{2 0 0} \mathbf{~ k D a}$ protein as the putative RGC collapsing factor}

Fractions from the second Mono S column were grouped into four pools as indicated by the bars in Figure $1 B$ : pool a included inactive fractions $9-13$, pool b included the partially active fractions 15-19, pool c included the early eluting active fractions 21-25, and pool d included the late eluting active fractions 27-31. The pools were dialyzed and concentrated. An equal volume of each was separated on a reducing SDS polyacrylamide gel and stained with Coomassie blue (Fig. 2A). A prominent band at 200 $\mathrm{kDa}$ was highly enriched in pools $\mathrm{c}$ and $\mathrm{d}$, coinciding with the high activity present in these pools. The $200 \mathrm{kDa}$ band was absent from pool a, whereas a faint band at $200 \mathrm{kDa}$ was sometimes visible in pool b on gels. Because the $200 \mathrm{kDa}$ protein was the only prominent protein that correlated with RGC collapsing activity, it seemed an excellent candidate for the RGC collapsing factor. The protein was eluted from a preparative gel and digested with trypsin, the fragments were separated by HPLC, and selected peptide fragments were subjected to microsequencing.

Peptide sequences were obtained from two distinct tryptic fragments. Comparison of these sequences with known sequences identify the purified protein as the bovine homolog of Slit2 (Table 2). Slit was originally characterized in Drosophila as a protein with homologies to epidermal growth factor sequence motifs and corresponding to the slit locus, a mutant that results in the disruption of axon tracts in the embryonic nervous system (Nusslein-Volhard et al., 1984; Rothberg et al., 1988). Slit was recently identified as the ligand for Robo, a guidance receptor on commissural and longitudinal axons in Drosophila (Kidd et al., 1999). Here we have purified Slit2 from bovine brains on the basis of its ability to induce the collapse of RGC growth cones.

\section{Recombinant Slit2 is a collapsing factor for RGC growth cones}

To confirm that Slit2 is an RGC collapsing factor, we cloned hSlit2 into a mammalian expression vector and applied recombinant hSlit 2 to cultured chick RGC axons. Two slit 2 constructs were generated. One construct expressed full-length untagged hSlit2 cDNA. The second construct (myc-his-hslit2) expressed hSlit2 with the SEMA-3A signal sequence, a double myc-tag, and a $6 \mathrm{x}$ His-tag at its N-terminus to aid the visualization and purification of expressed protein. Conditioned medium and cell membranes of 293T cells transfected with myc-his-hslit 2 were analyzed by Western blot and stained with an anti-myc antibody (Fig. 2B). Both membrane fractions and supernatants contain an $\sim 200 \mathrm{kDa}$ protein corresponding to full-length hSlit2. A $140 \mathrm{kDa}$ band is also detected and is particularly abundant in membrane fractions. This corresponds to the N-terminal fragment of hSlit2 that in mammalian cells has been shown to be generated through proteolytic processing (Brose et al., 1999; Wang et al., 1999). The RGC collapsing activity of recombinant hSlit2 was tested by adding conditioned medium from 293T cells that were either mock-transfected, transfected with hSlit2, or transfected with myc-his-hslit2 to cultured chick RGC explants. hSlit2 induced full collapse of RGC growth cones, thus confirming that Slit2 is a collapsing factor for RGC growth cones (Fig. 3B). The collapsing effect of recombinant hSlit2 on RGC growth cones was similar to that of the purified brain extract (Fig. 3A). Conditioned medium from mock-transfected cells did not induce growth cone collapse (Fig. 3B). Interestingly, we observed only a partial collapsing response with the N-terminally tagged version of hSlit2 (myc-hishslit2) (Fig. 3B). The collapsing response reached a plateau at $\sim 60 \%$ collapsed growth cones, even after the addition of large amounts of supernatant. We used untagged hSlit 2 in subsequent experiments because it was considerably more potent than the tagged version. 


\begin{tabular}{|c|c|c|c|c|}
\hline & Peptide1 & 1 & VDAFQDLHNLNLLSLYDNK & 19 \\
\hline m-Slit2 & AAD44759 & 389 & $\ldots \ldots \ldots \ldots \ldots$ & 407 \\
\hline r-Slit2 & AAD38940 & 441 & $\ldots \ldots \ldots \ldots \ldots$ & 459 \\
\hline h-Slit2 & AAD25539 & 393 & $\ldots \ldots \ldots \ldots \ldots$ & 411 \\
\hline m-Slit3 & AAD44760 & 396 & .NT . . . . . . . . . & 414 \\
\hline m-Slit1 & AAD44758 & 399 & $\ldots \ldots$. . . . . . . & 416 \\
\hline \multirow[t]{2}{*}{ D-Slit } & AAD26567 & 436 & 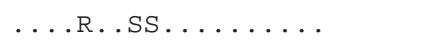 & 452 \\
\hline & Peptide2 & 1 & ITDIEEGAFEGASGVNEILLTSNR & 24 \\
\hline m-Slit2 & AAD44759 & 562 & $\ldots \ldots \ldots \ldots \ldots \ldots \ldots$ & 585 \\
\hline r-Slit2 & AAD38940 & 614 & $\ldots \ldots \ldots \ldots \ldots \ldots \ldots$ & 637 \\
\hline h-Slit2 & AAD25539 & 566 & $\ldots \ldots \ldots \ldots \ldots \ldots \ldots$ & 589 \\
\hline m-Slit3 & AAD44760 & 569 & .KEVR...D..AS.Q.LM..G.Q & 592 \\
\hline m-Slit1 & AAD44758 & 577 & VSE.D.T...AS.S.LH.A.Q & 600 \\
\hline D-slit & AAD26567 & 607 & L.G. .PN.....HIQ. LQ.GE.K & 630 \\
\hline
\end{tabular}

Peptides 1 and 2 obtained by the microsequencing of tryptic fragments of the $200 \mathrm{kDa}$ protein purified from bovine brain were compared to Slit sequences from different species. Both peptides are identical to sequences of mouse, rat, and human Slit2. Peptide 1 is part of the second LRR and peptide 2 is part of the third LRR of Slit2. The peptides show variable degrees of identity with m-slit1, m-slit3, and Drosophila Slit. Accession numbers of the Slit sequences obtained from GenBank are indicated in the second column. Peptide identities are indicated with a dot.

\section{Slit2 does not collapse DRG growth cones}

The native RGC collapsing activity purified from bovine brains (Mono S eluate) does not collapse DRG growth cones (data not shown). To determine whether recombinant hSlit2 shows the same specificity, hSlit2-conditioned medium was tested on chick DRG explants. As expected, recombinant hSlit2 had no effect on DRGs (Fig. 4). These data support the identification of Slit2 as the RGC collapsing activity purified from bovine brains.

\section{Slit2 induces collapse of RGC growth cones from all quadrants of the retina}

The retinotopic projection of $\mathrm{RGC}$ axons is organized in the anteroposterior axis by the graded distributions of ephrinA2 and ephrinA5 in the tectum and the complementary graded distribution of their receptors in retinal ganglion cells (Cheng et al., 1995; Drescher et al., 1995; Monschau et al., 1997). Less is known about how the dorsoventral retinotopic axis is organized. To determine whether Slit 2 might contribute to the establishment of either the anteroposterior or dorsoventral axis of the retinotectal projection, we tested whether RGCs originating from different retinal quadrants are differentially sensitive to Slit2. RGC growth cones extending from explants taken from nasal, temporal, dorsal, or ventral quadrants of the retina were all equally sensitive to both the native RGC collapsing activity we purified (data not shown) and to recombinant hSlit2 (Fig. 4). The same percentage of RGC growth cones collapsed in response to similar concentrations of hSlit2 regardless of their origin in the retina. These data make it doubtful that Slit2 plays a role in retinotopic mapping within the tectum.

\section{Slit2 repels RGC axons in collagen gel cocultures}

Chick retinal explants were cultured in a collagen-matrigel matrix 200-500 $\mu \mathrm{m}$ away from mock- or hSlit2-transfected 293T cell aggregates. These cocultures were fixed after $24 \mathrm{hr}$, and axons were visualized by immunostaining with neurofilament antibodies (Fig. 5). In 47 of 51 retinal explants, there was no axonal growth, or very limited growth, from the sides of the explants adjacent to Slit2-secreting cell aggregates (Fig. 5a). Moreover, axons extending from retinal explants appear to turn away from cell aggregates expressing hSlit 2 . In contrast, only 3 of 57 retinal explants had reduced axon outgrowth adjacent to mock-transfected cell aggregates (Fig. $5 b$ ). Thus, as predicted from the results of the growth cone collapse assay, hSlit 2 is a potent repellent for RGC axons.

\section{Expression patterns of Slits and Robos in the mouse visual system}

The first RGC axons grow out of the mouse retina at E12.5 and arrive at the chiasm by E13.5 (Silver, 1984). The majority of RGCs have processes that have traversed the chiasm by E15. Axons begin to reach their target areas by E16. We therefore performed in situ hybridization with probes for m-slit2 and its putative receptors m-robo1 and m-robo 2 on sections cut through the eye and chiasm regions of E12.5, E13.5, E15, and E16 mouse embryos. Two additional slit genes, slit1 and slit3, have been identified in vertebrates (Holmes et al., 1998; Itoh et al., 1998) and may have functions similar to slit2. A brief survey of their expression patterns was therefore initiated.

\section{Slit2 is expressed in the eye}

Slit2 is expressed in the inner retina in which RGCs would be expected to reside and in cells of the optic stalk at E13.5 (Fig. 6c). At this stage, it is also expressed in the outer edge of the retina (toward the periphery) and in the lens (Fig. 6c). At E16, slit2 mRNA is still detected in the inner retina but at a reduced level compared with E13.5 (Fig. 6d). Expression in the lens has also decreased at this stage. However, slit2 expression is prominent in a layer of cells surrounding the optic nerve (Fig. $6 d$ ).

\section{Slit1 is expressed in a pattern similar to Slit2}

Like slit2, slit1 is expressed in the inner retina of the mouse eye at E13.5 (Fig. 6a) and remains prominent through E16 (Fig. 6b). Unlike slit2, slit1 is detected in the olfactory epithelium at E16 (Fig. 6b). The distribution of slit3 is very different from those of slit1 and slit2. Slit3 mRNA is detected throughout the lens at E13.5 (Fig. 6e) and in the outer epithelial layer of the lens at E15 (Fig. $6 f$ ). Slit3 expression is abundant in other regions of the head outside the brain and visual system (Fig. $6 f$ and data not shown). 


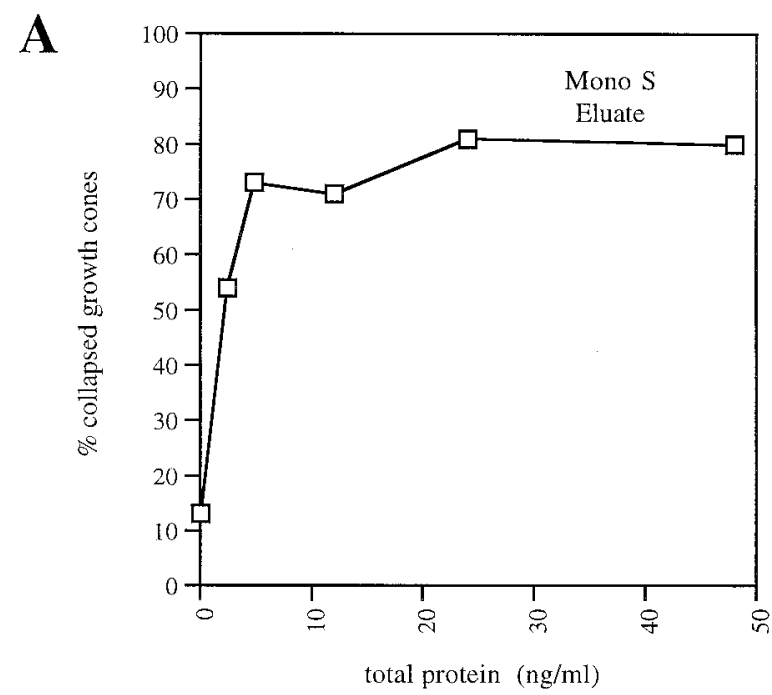

B

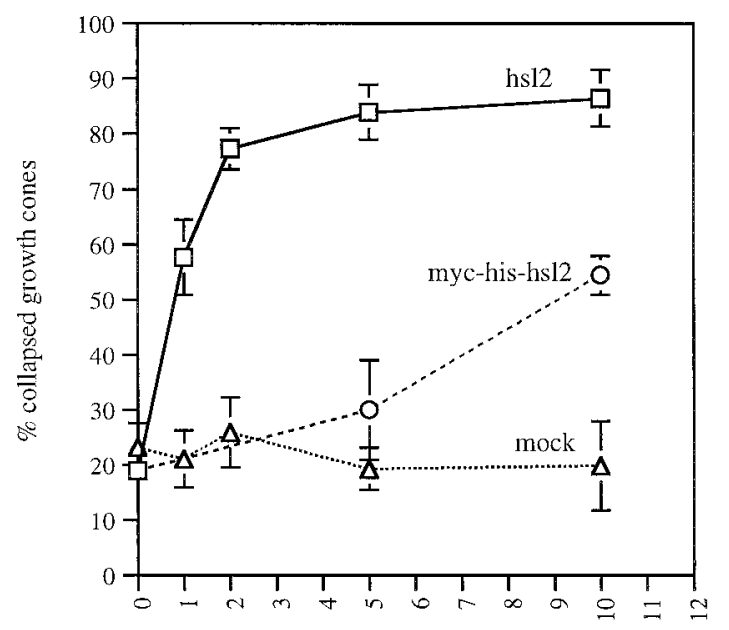

Supernatant added $(\mu \mathrm{l} / 500 \mu \mathrm{l})$

Figure 3. Purified brain extract and recombinant hSlit2 induce the collapse of RGC growth cones. $A$, Pool c of the second Mono $\mathrm{S}$ column (see Figs. $1 B, 2 A$ ) was added to the culture medium of E6 chick retinal explants at the indicated total protein concentration ( $x$-axis). After a 30 min incubation, the cells were fixed, and the percentage of collapsed growth cones was determined ( $y$-axis). The Mono S eluate elicits a potent, dose-dependent collapsing response in RGC growth cones. $B$, Supernatants from $293 \mathrm{~T}$ cells that were mock-transfected $(\triangle)$, transfected with hslit2 $(\square)$, or transfected with myc-his-hslit2 $(\bigcirc)$ were added to cultured E6 chick retinal explants. After a 30 min incubation, the cells were fixed, and the percentage of collapsed growth cones was determined. The percentages of collapsed growth cones are plotted against the volumes of cell supernatants added to $500 \mu \mathrm{l}$ of culture medium. Recombinant hslit2 elicits a strong collapsing response similar to the native purified protein, whereas myc-his-hslit2 induces a partial collapsing response.

\section{Slit receptors are expressed in the retinal ganglion cell layer}

Robo1, a putative receptor for Slit proteins, is first detected in the inner retina in which RGCs would be expected to reside at E13.5 (Fig. $6 g$ ). Its expression in the inner retina increases over time and is very pronounced in a subset of cells by E15 (Fig. 6h). Robo2, another putative Slit receptor, is strongly expressed throughout

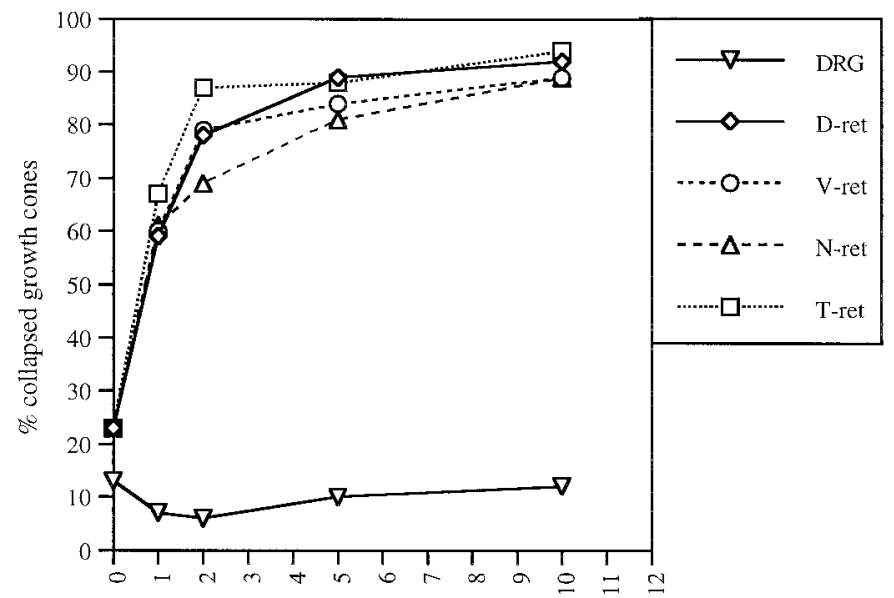

Supernatant added $(\mu \mathrm{l} / 500 \mu \mathrm{l})$

Figure 4. Recombinant hSlit2 induces the collapse of RGC growth cones from all retinal quadrants but does not affect DRG growth cones. Supernatant from hslit2-expressing 293T cells was added to cultured E6 chick retinal explants taken from dorsal $(D-r e t)$, ventral $(V$-ret $)$, nasal $(N$-ret $)$, and temporal (T-ret) retina or E7 chick DRGs. The percentages of collapsed growth cones are plotted against the volume of cell supernatant added to $500 \mu \mathrm{l}$ of culture medium. The collapsing response of RGC growth cones was similar in all retinal quadrants and comparable with that of explants from whole retina (compare with Fig. $3 B$ ). Note the absence of a collapsing response in DRG neurons.

the inner retina as early as E13.5 (Fig. 6i) and persists through E15 (Fig. 6j). The presence of robo1 and robo2 in the inner retina suggests that they are expressed by RGCs and is consistent with the ability of Slit2 to induce RGC growth cones to collapse. However, it is unclear at present which of the two receptors is most likely to confer responsiveness to Slit2. Neither robo1 nor robo 2 are expressed in a nasal-temporal gradient within the retina (Fig. $6 g-j$ ). We were also unable to detect a dorsoventral gradient of expression on coronal sections (data not shown). This is consistent with the collapse assays, which show that all chick ganglion cells respond equally well to Slit2.

\section{Slit2 is expressed in the optic stalk}

Slit2 expression was further analyzed on horizontal sections through the developing optic nerve. Slit2 is already present in cells within the optic stalk at E12.5 (Fig. 7a). Very few neurofilament-positive RGC axons have entered the optic stalk at this stage (Fig. $7 b, c$ ). Slit2 expression is prominent in the E13.5 stalk (Fig. 7d), by which time a large number of RGC axons are seen adjacent to slit2-expressing cells (Fig. 7e,f). Slit2 is expressed at the exit of the eye in dorsal stalk cells, between the pigment epithelial cells and the RGC axons (data not shown). Slit2 expression is most prominent in cells within the center of the stalk, whereas RGC axons are apposed to the ventral wall of the stalk. This complementary pattern of neurofilament staining and slit2 expression is seen all along the optic stalk and at the base of the diencephalon (Fig. 7g-i).

\section{Slit2 is expressed at the ventral midline but not where the optic chiasm forms}

Slit2 is strongly expressed throughout the developing hypothalamus in regions anterior to the path that optic fibers take to the midline. Upon reaching the brain, neurofilament-positive axons are seen to grow posteriorly into an area in which slit2 is not 

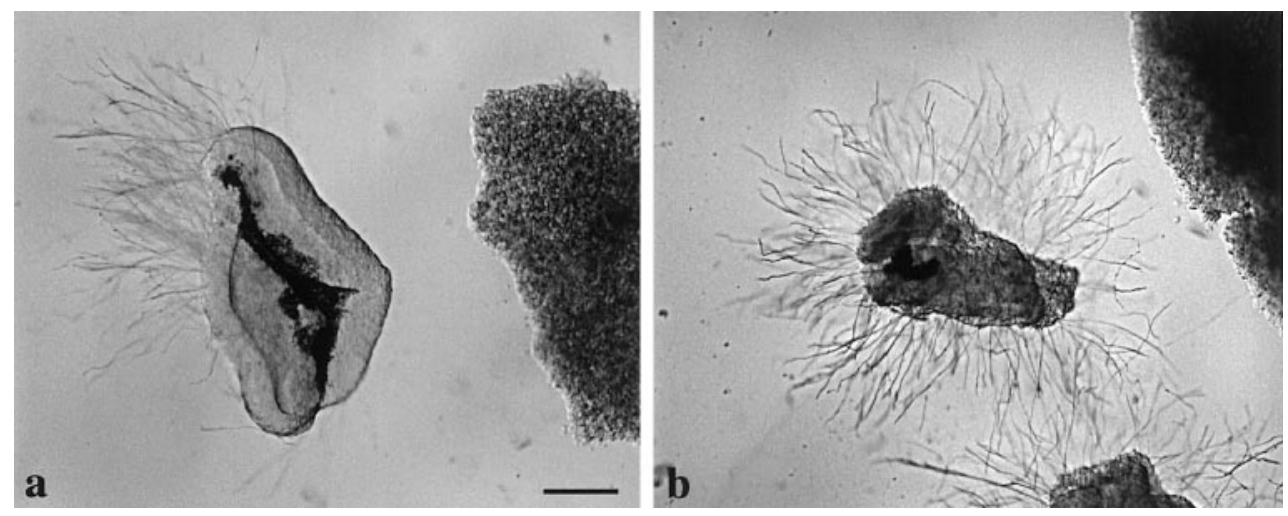

Figure 5. Slit2 is a potent chemorepellent for RGC axons. E6 chick retinal explants were cocultured with aggregates of hslit2-transfected $(a)$ or mock-transfected (b) $293 \mathrm{~T}$ cells in collagen-matrigel. Explants were positioned at $200-500 \mu \mathrm{m}$ from the cell aggregates. The cultures were fixed after $24 \mathrm{hr}$, and axons were visualized by neurofilament immunostaining. Outgrowth of retinal axons was essentially absent on the side of the explant facing slit2-expressing aggregates $(a)$. No differential growth is seen in the presence of control cells $(b)$. Scale bar, $200 \mu \mathrm{m}$.

expressed (Fig. $7 g-l$ ). Slit2 expression was further investigated in horizontal sections (Fig. $8 a-c$ ) and coronal sections (Fig. $8 d-l$ ) through the ventral midline of the diencephalon at E13.5. The pattern of neurofilament staining in the developing optic chiasm is again complementary to the expression of slit2. As seen on horizontal sections, slit2 expression is very prominent in the anterior hypothalamus but is absent from posterior regions at which retinal fibers cross the ventral midline (Fig. $8 a-c$ ). This is confirmed in serial coronal sections through the ventral diencephalon (Fig. $8 d-l$ ). Although slit2 expression is high in the ventral midline of the anterior portion of the hypothalamus (Fig. 8d), there is no detectable expression further caudally where RGC axons cross the midline in the chiasm (Fig. 8j). The complementary distributions of slit 2 expression and neurofilament staining are consistent with the inference that slit 2 acts as a repellent for RGC axons in vivo.

\section{DISCUSSION}

In a search for novel guidance molecules that repel RGC axons, we purified a protein from bovine brain that induces the collapse of chick RGC growth cones. The $200 \mathrm{kDa}$ protein we isolated is full-length Slit2. Like the native collapsing activity we purified, recombinant hSlit 2 collapses $\mathrm{RGC}$ growth cones from all retinal quadrants and has no collapsing effect on DRG growth cones. RGC axons grow away from hSlit2-expressing cells in a threedimensional gel assay. Slit2 mRNA is expressed in the inner layer of the mouse retina, in cells of the optic stalk, and in the ventral diencephalon. Slit2 expression is particularly strong in the developing anterior hypothalamus, whereas no expression is seen at the optic chiasm when RGC axons cross the ventral midline. The trajectories of RGC axons are complementary to slit2-expressing cells. Two other mouse slit genes, slit1 and slit3, are expressed in the developing eye and in some areas along the RGC axon pathway (data not shown). The putative Slit receptors, robo1 and robo2, are detected in the inner retina in which retinal ganglion cells reside. These results suggest that Slit2 acts as a repellent guidance cue for RGC axons in the developing vertebrate embryo. Similar results have been obtained by two other groups working independently (Erskine et al., 2000; Ringstedt et al. 2000).

Slit is a large, secreted extracellular matrix protein (Rothberg et al., 1990). Drosophila Slit was recently identified as the ligand for Robo, a transmembrane protein of the Ig superfamily (Kidd et al., 1999). In the fly nervous system, Slit functions as a shortrange axon repellent that prevents responsive axons from crossing at the midline. In the absence of Slit, commissures do not form and longitudinal axon fascicles form and extend at the midline (Rothberg et al., 1988; Kidd et al., 1999). Loss of Robo, a receptor for this midline repellent, leads to axons that cross the midline promiscuously and generate the "roundabout" phenotype (Seeger et al., 1993; Kidd et al., 1998). Drosophila Slit also functions as a long-range repellent for migrating muscle precursor cells (Kidd et al., 1999).

Three slit genes have been isolated in vertebrates: slit1, slit2, and slit3 (Holmes et al., 1998; Itoh et al., 1998). Slit2 was shown previously to repel axons growing from ventral spinal cord, olfactory bulb, and dentate gyrus explants, and to induce growth cone collapse in olfactory bulb and hippocampal neurons (Brose et al., 1999; Li et al., 1999; Nguyen Ba-Charvet et al., 1999). A 140 kDa $\mathrm{N}$-terminal fragment of Slit2 (Slit2-N) was recently purified as a factor that stimulates outgrowth and branching of DRG axons in vitro (Wang et al., 1999). In this particular assay, full-length Slit2 has no such activity but does interfere with the activity of Slit2-N. In addition to orienting axons, Slit1 and Slit2 function as repellent guidance signals for migrating cells, e.g., olfactory bulb precursors and cortical GABAergic neurons (Wu et al., 1999; Zhu et al., 1999). Although we have confined our analysis to the effects of Slit2 on RGC axons, both slit1 and slit3 are expressed in the vicinity of the retinal axon trajectories, and their effects on RGC growth cones should be examined in the future.

\section{Full-length Slit2 is a collapsing factor for RGC growth cones}

Several lines of evidence indicate that full-length Slit2 is the retinal collapsing activity enriched by our biochemical procedures. (1) A single major protein band of $200 \mathrm{kDa}$, the predicted molecular weight for full-length Slit2, was detected in the active pool after the last purification step. (2) Peptide sequences obtained from this protein were identical to sequences from human, mouse, and rat Slit2. (3) Like the native activity we purified, recombinant hSlit2 collapses RGC growth cones from all retinal quadrants and does not collapse DRG growth cones. (4) Recombinant hSlit2 repels RGC axons in collagen gels. (5) Slit2 is expressed in a pattern that is complementary to the trajectories of retinal axons during mouse embryogenesis.

Recombinant Slit2 produced in cell culture is proteolytically processed to generate two shorter fragments in addition to fulllength Slit2 (Brose et al., 1999; Wang et al., 1999) (see also Fig. $2 B$ herein). The $\mathrm{N}$-terminal $140 \mathrm{kDa}$ fragment promotes outgrowth and induces branching of DRG axons in culture (Wang et al., 1999). Our most purified RGC collapsing fractions did not appear to contain significant bands corresponding to either the $\mathrm{N}$ or C-terminal fragments. We therefore ascribe our purified native activity to full-length Slit2. 

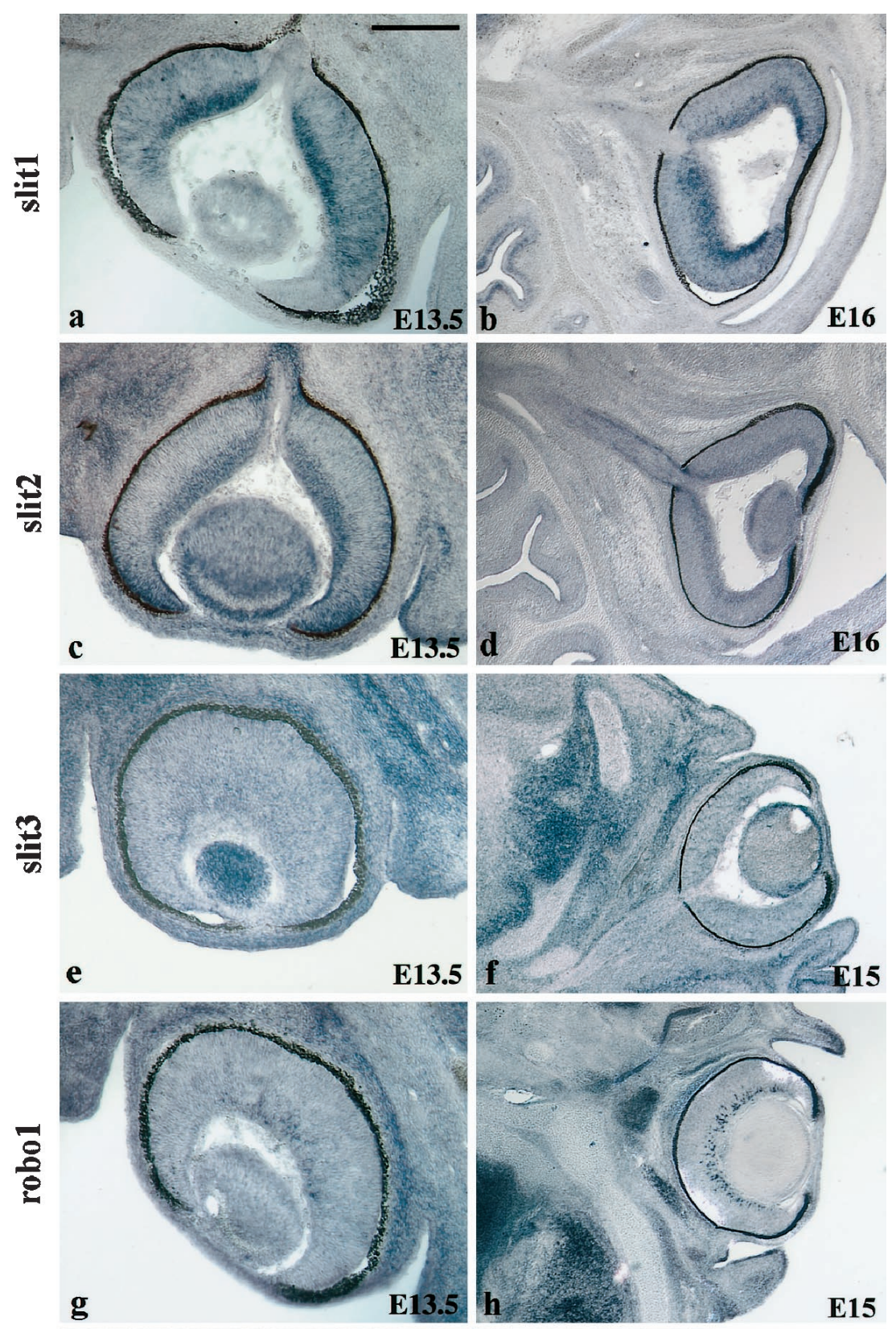

Figure 6. Slit and Robo mRNAs are expressed in the
developing mouse eye. Horizontal sections through the head of mouse embryos taken at the indicated stages were hybridized with DIG-labeled riboprobes for m-slit1, m-slit2, m-slit3, m-robo1, and m-robo2. Staining for slit 1 and slit2 mRNA is detected in the E13.5 and E16 ganglion cell layer of the retina. Slit2 mRNA is also seen in the lens and in the optic nerve at E13.5 and E16. Slit3 mRNA is strongly expressed in the lens at E13.5 and is still seen in the outer cell layer of the E15 lens. Robo1 is expressed in a subset of cells in the inner retinal layer at E13.5 that becomes more intense at E15. Robo2 is expressed in the inner retinal layer at E13.5 and E15, and its expression pattern is broader and more diffuse compared with robo1. Scale bar: $a, c, e, g, i, 100 \mu \mathrm{m} ; b, d, f, h, j, 200 \mu \mathrm{m}$.
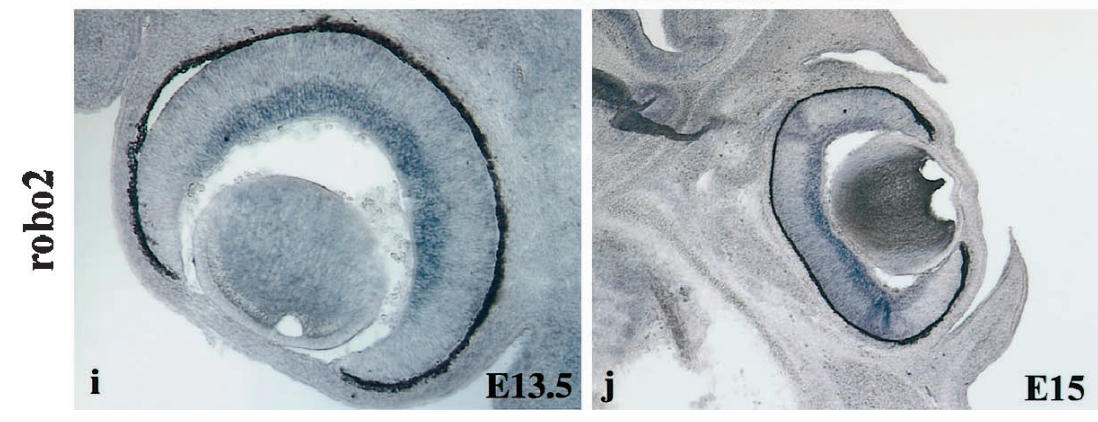

tation is not dependent solely on this cue, however, because their correct orientation is preserved in netrin-1-deficient mice (Deiner et al., 1997). Chondroitin sulfate proteoglycans localized to the periphery of the inner retina have been proposed to help orient RGC extension through a repellent mechanism (Snow et al., 1991). Enzymatic removal of chondroitin sulfates from cultured retinas induces ectopic positioning of RGCs and disorga-

\section{Role of Slit2 in RGC axon pathfinding Intraretinal guidance}

The initial outgrowth of RGC axons within the retina is highly directed as axons extend along the vitreal surface toward the optic disk (Halfter et al., 1985). Netrin-1 has been shown to be an attractant for RGC axons and helps draw them toward the optic disk (De la Torre et al., 1997; Deiner et al., 1997). RGC orien- 

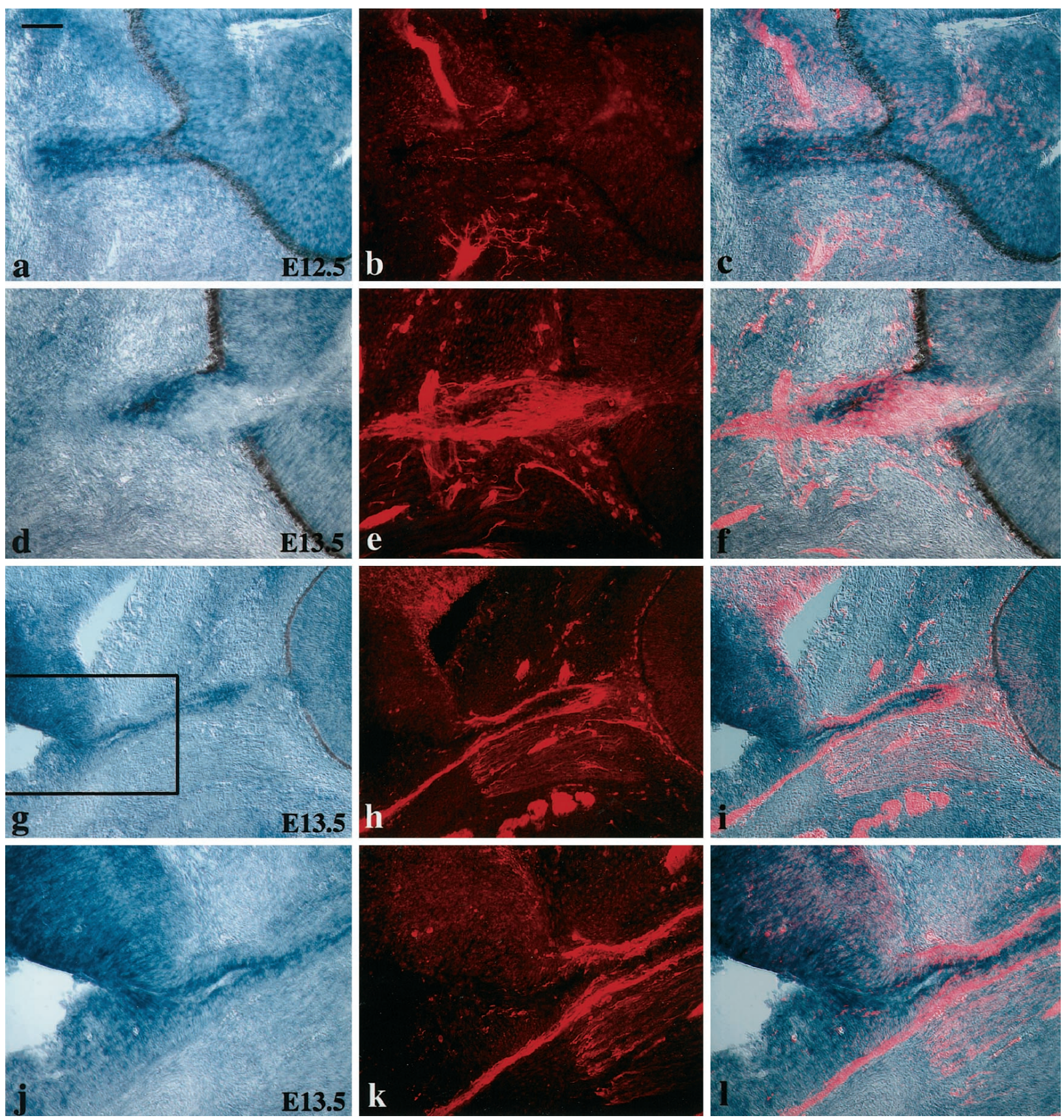

Figure 7. Slit2 mRNA staining is complementary to fiber growth in the developing optic nerve. Left panels show the in situ hybridization signal for $\mathrm{m}$-slit2. Middle panels show the identical sections stained with an anti-neurofilament antibody. Right panels show an overlay of the neurofilament staining onto the slit2 in situ signal. Horizontal sections through the mouse brain at E12.5 and E13.5. Anterior is to the top, and posterior is to the bottom. Slit2 mRNA is detected at the optic nerve head at E12.5 $(a)$ and E13.5 $(d)$ and throughout the ventricular lining of the optic stalk at E13.5 $(g, h) . j$ is a higher magnification of the boxed area in $g$. Note the striking complementarity in the neurofilament staining and the slit 2 in situ signal. Scale bar: $a, d, j, 50 \mu \mathrm{m}$; $g, 100 \mu \mathrm{m}$.

nized axon outgrowth in all directions (Brittis et al., 1992). These molecules may therefore help explain the directed centripetal growth of RGC axons in the eye; however, it should be noted that other ECM components bound to chondroitin sulfates may have been released by these manipulations. Because Slit 2 is expressed in the inner retina, in the outer peripheral retina, and in the lens (Fig. 6c), it too might be a candidate repellent that could help direct RGC axons first toward the vitreal surface and then from the periphery toward the optic disk. It was reported recently that the lens secretes an activity that repels RGC axons from all retinal quadrants (Ohta et al., 1999). The high expression of slit3 in the lens suggests the possibility of similar repellent roles for Slit2 and Slit3 that might help direct early growing RGC axons toward the center of the eye. It would therefore be interesting to determine whether Slit3 collapses RGC growth cones in vitro.

It is somewhat surprising that slit 1 and slit 2 are expressed along with their putative robo receptors in the retina. The coexpression of receptors and repellent ligands is an emerging pattern that 

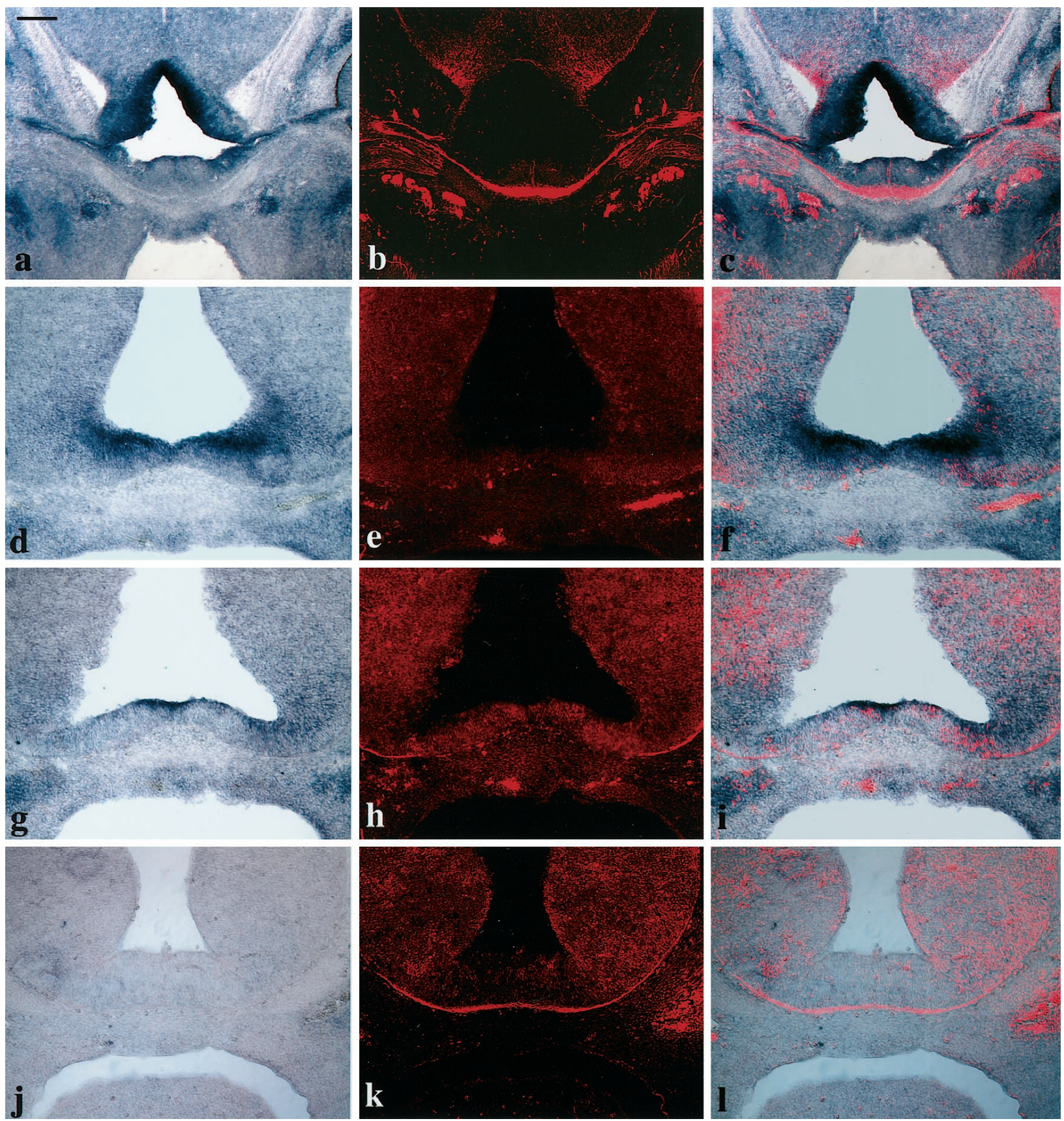

Figure 8. Slit2 mRNA is expressed in the ventral diencephalon but is absent from the path of growing fibers. Left panels show the in situ hybridization signal for m-slit2. Middle panels show the identical sections stained with an anti-neurofilament antibody. Right panels show an overlay of the neurofilament staining on the slit 2 in situ signal. Horizontal $(a)$ and coronal $(d, g, j)$ sections through the region of the optic chiasm in an E13.5 mouse. In $(a)$ anterior is to the top. Coronal sections are shown from anterior $(d)$ to posterior $(j)$. Note that slit2 expression is strong in the developing hypothalamus in its rostral portion and in the ventricular lining of the optic stalk but it is absent from the chiasmiatic region in which retinal fibers meet to cross over to the contralateral optic tract. Scale bar: $a, 200 \mu \mathrm{m} ; d, g, j, 100 \mu \mathrm{m}$.

seems to be recapitulated in multiple axonal guidance systems. For example, ephrins expressed in the retina are thought to modulate the sensitivity of RGCs for ephrins expressed in the target (Hornberger et al., 1999). The coexpression of SEMA-1A and its receptor Plexin $\mathrm{A}$ in insect motor neurons modulates the tendency of motor axons to defasciculate at defined choice points (Winberg et al., 1998; Yu et al., 1998). It is therefore tempting to speculate that coexpression of Slits and their receptors in RGCs modulates their responsiveness to Slits in other more distal portions of their trajectories. Alternatively Slits expressed in the cellular layers of the retina may help to confine RGC axon extension to the vitreal margin of the retina.

\section{Guidance in the optic nerve}

Before the extension of the first pioneering optic fibers (which leave the retina at E12.5 in the mouse), the ventralmost wall of the eye invaginates to form the optic fissure. This invagination continues along the ventral wall of the stalk in which optic fibers will later advance (Silver and Sapiro, 1981). Axons always enter the stalk in its ventralmost margin, apparently avoiding pig- 
mented cells in the dorsal stalk (Silver and Sapiro, 1981). Pioneer axons extend within the ventral groove of the stalk all the way to the chiasm. Later arriving axons fasciculate with the pioneer axons to form tight bundles in the ventral stalk. Slit2 expression is detected in the optic stalk between E12.5 and E16.5, presumably in the neuroepithelial cells that form the stalk and later give rise to mature glial cells (Silver, 1984). RGC axons travel immediately adjacent to slit2-expressing stalk cells, a surprising finding if Slit2 is acting as a soluble repellent in vivo. What can account for this close proximity of Slit 2 and responsive RGC axons?

One possibility is that Slit2 acts as a repellent but is not diff usible in vivo. We purified Slit 2 from brain membranes and the protein remains primarily membrane-associated when expressed in mammalian cell lines (Fig. 2B), suggesting that Slit2 acts as a local rather than a long-range guidance cue. It is thus possible that slit2-positive cells in the stalk form a boundary that channels RGC axons into the groove of the invaginated stalk. Indeed RGC axons do not appear to be intermingled with slit2-expressing cells; rather, they grow adjacent to and at later stages (E15-E16) surrounded by these cells (Figs. 6-8). Slit2 expressed in dorsal stalk cells may help direct RGC axons into the ventralmost margin of the stalk in which the optic nerve leaves the eye. Further along the stalk, the presence of slit 2 in immediately adjacent cells is likely to promote the very high degree of axon fasciculation observed in the optic nerve. Thus, Slit2 may confine retinal fiber growth in the ventral margin of the optic stalk, channeling their extension to the brain and promoting their strong fasciculation.

A second diametrically opposed possibility is that Slit2 does not act as a repellent in vivo. Recent findings suggest that guidance cues may act as either repellents or attractants depending on the levels of cyclic nucleotides in responding axons. For example, SEMA-3A can be converted from a repellent into an attractant by raising cGMP levels (Song et al., 1998). Similarly, netrin-1 can be converted from an attractant to a repellent in the presence of a competitive cAMP analog (Ming et al., 1997). Although Slit2 acts as a repellent for RGC axons in culture, it is possible that it acts as an attractant under the conditions that pertain in vivo. High levels of slit 2 in the neuroepithelial cells of the stalk might then promote retinal axon penetration and extension. Arguing against this possibility, however, is the obvious failure of RGC axons to invade the entire slit2-expressing stalk. For this reason, it seems most likely that Slit2 acts as a short-range repellent in vivo. Differentiating between these opposing hypotheses will require the examination of RGC axon trajectories in embryos misexpressing Slit2.

\section{Guidance in the chiasmatic area}

Another role that Slit2 could play is to help define where RGC axons grow into the brain and where they cross the ventral midline of the CNS. Slit2 is strongly expressed in the anterior ventral diencephalon (Fig. 7). As they approach the midline, RGC axons turn caudally away from slit2-expressing cells. Although slit 2 expression is very strong at the ventral midline of the rostral diencephalon, expression progressively decreases caudally and is absent at the level of the optic chiasm. The location at which retinal axons can cross the midline, and therefore the position of the optic chiasm, may in part be determined by the absence of slit 2 expression. The absence of slit 2 in the chiasm and the apparently uniform distribution of robos in the retina make it unlikely that Slit 2 plays an important role in keeping temporal retinal axons with ipsilateral targets from crossing the midline.

Region-specific cues present in the diencephalon have been proposed to guide RGC axons along the dorsoventral axis of the diencephalon (Tuttle et al., 1998). A soluble repulsive activity for retinal axons is detected in explants from rostral hypothalamus and epithalamus but is absent in caudal hypothalamus and thalamus, whereas a growth-stimulatory activity is present in thalamus (Tuttle et al., 1998). The strong expression of slit 2 in rostral but not caudal hypothalamus could account at least in part for the observed repulsive effects of these tissues. Other RGC repellent activities detected in culture might be similarly explained. For example, floor plate explants repel RGC axons and express high levels of slit2 mRNA (Wang et al., 1996; Brose et al., 1999).

RGC axons establish topographically correct connections with neurons in their brain targets. EphrinA2 and ephrinA5 are crucial for retinotectal map formation in the anteroposterior axis $(\mathrm{Na}-$ kamoto et al., 1996; Frisen et al., 1998). EphrinB family members have been proposed to play a role in topographic mapping along the dorsoventral axis (O'Leary and Wilkinson, 1999). Slit2 is not expressed in gradients in either the anteroposterior or the dorsoventral axis. Moreover, chick RGCs from all parts of the eye are equally sensitive to Slit 2 in our in vitro assay, and its receptors, robo1 and robo2, are uniformly distributed in the mouse retina (Fig. 6). These results make it very unlikely that Slit2 contributes to topographic retinotectal mapping.

Our results suggest that Slit2 is a chemorepellent guidance signal for RGC axons and, together with other guidance cues, helps to define the trajectories of optic nerve fibers. In particular, Slit2 is a candidate guidance cue that could help direct RGC axons away from the periphery of the eye toward the optic nerve head, provide a boundary that funnels RGC axons into the ventral optic stalk on their path to the brain, and define where RGC axons cross the ventral midline at the optic chiasm. Determining which of these roles Slit2 actually plays during RGC axon pathfinding will require the perturbation of slit 2 expression, or neutralizing the function of its receptors, in vivo.

\section{REFERENCES}

Baird JL, Raper JA (1995) A serine proteinase involved in contact mediated repulsion of retinal growth cones by DRG neurites. J Neurosci 15:6605-6618.

Brittis PA, Canning DR, Silver J (1992) Chondroitin sulfate as a regulator of neuronal patterning in the retina. Science 255:733-736.

Brittis PA, Lemmon V, Rutishauser U, Silver J (1995) Unique changes of ganglion cell growth cone behavior following cell adhesion molecule perturbations: a time-lapse study of the living retina. Mol Cell Neurosci $6: 433-449$

Brose K, Bland KS, Wang KH, Arnott D, Henzel W, Goodman CS, Tessier-Lavigne M, Kidd T (1999) Slit proteins bind Robo receptors and have an evolutionarily conserved role in repulsive axon guidance. Cell 96:795-806.

Cheng H, Nakamoto M, Bergemann A, Flanagan J (1995) Complementary gradients in expression and binding of ELF-1 and Mek4 in development of the topographic retinotectal projection map. Cell 82:371-381.

De la Torre JR, Hopker VH, Ming GL, Poo MM, Tessier-Lavigne M, Hemmati-Brivanlou A, Holt CE (1997) Turning of retinal growth cones in a netrin-1 gradient mediated by the netrin receptor DCC. Neuron 19:1211-1224.

Deiner MS, Kennedy TE, Fazeli A, Serafini T, Tessier-Lavigne M, Sretavan DW (1997) Netrin-1 and DCC mediate axon guidance locally at the optic disc: loss of function leads to optic nerve hypoplasia. Neuron 19:575-589.

Drescher U, Kremoser C, Handwerker C, Loschinger J, Noda M, Bonhoeffer F (1995) In vitro guidance of retinal ganglion cell axons by RAGS, a $25 \mathrm{kDa}$ tectal protein related to ligands for Eph receptor tyrosine kinases. Cell 82:359-370.

Erskine L, Williams SE, Brose K, Kidd T, Rachel RA, Goodman CS, Tessier-Lavigne M, Mason CA (2000) Retinal ganglion cell axon guidance in the mouse optic chiasm: expression and function of Robos and Slits. J Neurosci, in press. 
Feldheim DA, Vanderhaeghen P, Hansen MJ, Frisen J, Lu Q, Barbacid M, Flanagan JG (1998) Topographic guidance labels in a sensory projection to the forebrain. Neuron 21:1303-1313.

Frisen J, Yates PA, McLaughlin T, Friedman GC, O'Leary DD, Barbacid M (1998) Ephrin-A5 (AL-1/RAGS) is essential for proper retinal axon guidance and topographic mapping in the mammalian visual system. Neuron 20:235-243.

Halfter W, Deiss S, Schwarz U (1985) The formation of the axonal pattern in the embryonic avian retina. J Comp Neurol 232:466-480.

Holmes GP, Negus K, Burridge L, Raman S, Algar E, Yamada T, Little MH (1998) Distinct but overlapping expression patterns of two vertebrate slit homologs implies functional roles in CNS development and organogenesis. Mech Dev 79:57-72.

Hornberger MR, Dutting D, Ciossek T, Yamada T, Handwerker C, Lang S, Weth F, Huf J, Wessel R, Logan C, Tanaka H, Drescher U (1999) Modulation of EphA receptor function by coexpressed ephrinA ligands on retinal ganglion cell axons. Neuron 22:731-742.

Itoh A, Miyabayashi T, Ohno M, Sakano S (1998) Cloning and expressions of three mammalian homologues of Drosophila slit suggest possible roles for Slit in the formation and maintenance of the nervous system. Brain Res Mol Brain Res 62:175-186.

Kidd T, Brose K, Mitchell KJ, Fetter RD, Tessier-Lavigne M, Goodman CS, Tear G (1998) Roundabout controls axon crossing of the CNS midline and defines a novel subfamily of evolutionarily conserved guidance receptors. Cell 92:205-215.

Kidd T, Bland KS, Goodman CS (1999) Slit is the midline repellent for the robo receptor in Drosophila. Cell 96:785-794.

Koppel AM, Feiner L, Kobayashi H, Raper JA (1997) A 70 amino acid region within the semaphorin domain activates specific cellular response of semaphorin family members. Neuron 19:531-537.

Li HS, Chen JH, Wu W, Fagaly T, Zhou L, Yuan W, Dupuis S, Jiang ZH, Nash W, Gick C, Ornitz DM, Wu JY, Rao Y (1999) Vertebrate slit, a secreted ligand for the transmembrane protein roundabout, is a repellent for olfactory bulb axons. Cell 96:807-818.

Luo Y, Raible D, Raper JA (1993) Collapsin: a protein in brain that induces the collapse and paralysis of neuronal growth cones. Cell 75:217-227.

Mason CA, Sretavan DW (1997) Glia, neurons, and axon pathfinding during optic chiasm development. Curr Opin Neurobiol 7:647-653.

McFarlane S, Cornel E, Amaya E, Holt CE (1996) Inhibition of FGF receptor activity in retinal ganglion cell axons causes errors in target recognition. Neuron 17:245-254.

Ming GL, Song HJ, Berninger B, Holt CE, Tessier-Lavigne M, Poo MM (1997) cAMP-dependent growth cone guidance by netrin-1. Neuron 19:1225-1235.

Monschau B, Kremoser C, Ohta K, Tanaka H, Kaneko T, Yamada T, Handwerker C, Hornberger MR, Loschinger J, Pasquale EB, Siever DA, Verderame MF, Muller BK, Bonhoeffer F, Drescher U (1997) Shared and distinct functions of RAGS and ELF-1 in guiding retinal axons. EMBO J 16:1258-1267.

Nakamoto M, Cheng HJ, Friedman GC, McLaughlin T, Hansen MJ, Yoon CH, O'Leary DD, Flanagan JG (1996) Topographically specific effects of ELF-1 on retinal axon guidance in vitro and retinal axon mapping in vivo. Cell 86:755-766.

Nguyen Ba-Charvet KT, Brose K, Marillat V, Kidd T, Goodman CS, Tessier-Lavigne M, Sotelo C, Chedotal A (1999) Slit2-Mediated chemorepulsion and collapse of developing forebrain axons. Neuron 22:463-473.

Nusslein-Volhard C, Wieschaus E, Kluding H (1984) Mutations affecting the pattern of the larval cuticle in Drosophila melanogaster. I. Zygotic loci on the second chromosome. Rouxs Arch Dev Biol 193:267-282.

O'Leary DD, Wilkinson DG (1999) Eph receptors and ephrins in neural development. Curr Opin Neurobiol 9:65-73.

O'Leary DD, Yates PA, McLaughlin T (1999) Molecular development of sensory maps: representing sights and smells in the brain. Cell 96:255-269.
Ohta K, Tannahill D, Yoshida K, Johnson AR, Cook GM, Keynes RJ (1999) Embryonic lens repels retinal ganglion cell axons. Dev Biol 211:124-132.

Ringstedt T, Braisted JE, Brose K, Kidd T, Goodman C, Tessier-Lavigne M, O'Leary DDM (2000) Slit inhibition of retinal axon growth and its role in retinal axon pathfinding and innervation patterns within the diencephalon. J Neurosci, in press.

Rothberg JM, Hartley DA, Walther Z, Artavanis-Tsakonas S (1988) slit: an EGF-homologous locus of D. melanogaster involved in the development of the embryonic central nervous system. Cell 55:1047-1059.

Rothberg JM, Jacobs JR, Goodman CS, Artavanis-Tsakonas S (1990) slit: an extracellular protein necessary for development of midline glia and commissural axon pathways contains both EGF and LRR domains. Genes Dev 4:2169-2187.

Seeger M, Tear G, Ferres-Marco D, Goodman CS (1993) Mutations affecting growth cone guidance in Drosophila: genes necessary for guidance toward or away from the midline. Neuron 10:409-426.

Shepherd I, Luo Y, Raper JA, Chang S (1996) The distribution of collapsin-1 mRNA in the developing chick nervous system. Dev Biol 173:185-199.

Silver J (1984) Studies on the factors that govern directionality of axonal growth in the embryonic optic nerve and at the chiasm of mice. J Comp Neurol 223:238-251.

Silver J, Sapiro J (1981) Axonal guidance during development of the optic nerve: the role of pigmented epithelia and other extrinsic factors. J Comp Neurol 202:521-538.

Snow DM, Watanabe M, Letourneau PC, Silver J (1991) A chondroitin sulfate proteoglycan may influence the direction of retinal ganglion cell outgrowth. Development 113:1473-1485.

Song H, Ming G, He Z, Lehmann M, McKerracher L, Tessier-Lavigne M, Poo M (1998) Conversion of neuronal growth cone responses from repulsion to attraction by cyclic nucleotides. Science 281:1515-1518.

Sretavan DW, Pure E, Siegel MW, Reichardt LF (1995) Disruption of retinal axon ingrowth by ablation of embryonic mouse optic chiasm neurons. Science 269:98-101.

Tuttle R, Braisted JE, Richards LJ, O'Leary DD (1998) Retinal axon guidance by region-specific cues in diencephalon. Development 125:791-801.

Walz A, McFarlane S, Brickman YG, Nurcombe V, Bartlett PF, Holt CE (1997) Essential role of heparan sulfates in axon navigation and targeting in the developing visual system. Development 124:2421-2430.

Wang KH, Brose K, Arnott D, Kidd T, Goodman CS, Henzel W, Tessier-Lavigne M (1999) Biochemical purification of a mammalian slit protein as a positive regulator of sensory axon elongation and branching. Cell 96:771-784.

Wang LC, Dani J, Godement P, Marcus RC, Mason CA (1995) Crossed and uncrossed retinal axons respond differently to cells of the optic chiasm midline in vitro. Neuron 15:1349-1364.

Wang LC, Rachel RA, Marcus RC, Mason CA (1996) Chemosuppression of retinal axon growth by the mouse optic chiasm. Neuron 17:849-862.

Winberg ML, Noordermeer JN, Tamagnone L, Comoglio PM, Spriggs MK, Tessier-Lavigne M, Goodman CS (1998) Plexin A is a neuronal semaphorin receptor that controls axon guidance. Cell 95:903-916.

Wizenmann A, Thanos S, von Boxberg Y, Bonhoeffer F (1993) Differential reaction of crossing and non-crossing rat retinal axons on cell membrane preparations from the chiasm midline: an in vitro study. Development 117:725-735.

Wu W, Wong K, Chen J, Jiang Z, Dupuis S, Wu JY, Rao Y (1999) Directional guidance of neuronal migration in the olfactory system by the protein Slit. Nature 400:331-336.

Yu HH, Araj HH, Ralls SA, Kolodkin AL (1998) The transmembrane Semaphorin Sema I is required in Drosophila for embryonic motor and CNS axon guidance. Neuron 20:207-220.

Zhu Y, Li H, Zhou L, Wu JY, Rao Y (1999) Cellular and molecular guidance of GABAergic neuronal migration from an extracortical origin to the neocortex. Neuron 23:473-485. 